\title{
Competence-based Education and Training Model for Management Team of School Operational Assistance
}

\author{
Kusnandar, Aan Komariah", Soemarto, Udin Syaefudin Sa'ud \\ Educational Administration, Universitas Pendidikan Indonesia, Indonesia \\ Received October 27, 2019; Revised March 3, 2020; Accepted March 15, 2020
}

Copyright $\odot 2020$ by authors, all rights reserved. Authors agree that this article remains permanently open access under the terms of the Creative Commons Attribution License 4.0 International License

\begin{abstract}
This study aims to develop a competence-based training model for management team of school operational assistance (BOS) in order to improve financial accountability in Primary Education level in Purwakarta Regency, Indonesia. This research used ADDIE (Analysis-Design-Develop-Implement-Evaluate) research and development model approach. Results of the research show that in stage of training needs assessment, there are some needs of training participants in the forms of ability in understanding the BOS Technical Guidance, ability in implementing BOS Planning, ability in implementing BOS management, ability in reporting BOS funds and ability in using BOS funds reporting application which all of the abilities can be created through development of this competence-based training model. Results of the training needs assessment are then developed into a training design and tested in a limited manner before it is implemented. Implementation of competence-based education and training model show effectiveness of learning outcome achievement which is supported by systematic and correlation between components. Application of competence-based education and training model for management team of BOS funds in Purwakarta Regency is conducted effectively after monitoring and evaluation process on the implementation of training model development. Therefore, the development of training model provide positive effects on improvement of BOS funds manager team competence as it has been inventoried in the needs assessment.
\end{abstract}

Keywords Financial Accountability, School Operational Assistance, Competence-based Training

\section{Introduction}

Accountability of an education financing management implementation is an absolute thing achieved by school financial managers. As described by (Castetter, 1999) that performance standard conceptually and commonly covers professional ability, social ability and personal ability aspects. One of the outputs of BOS funds management implementation is by stating an accountable financial reporting of BOS management results by Audit Board of the Republic of Indonesia. However, based on results of preliminary studies, there has been a gap between training conducted by Education Office of Purwakarta Regency and effects of the training on results of BOS funds management implementation by school parties. Then, the gap can be proven by audit results of BPK which it is still found not-accountable financial reporting results of BOS funds management in 2017.

Based on results of the study in Education Office of Purwakarta Regency as the training organizer, there is information stating that education and training is not conducted effectively and efficiently. In its implementation, the education and training only has focus on socialization of technical instructions on implementation of BOS funds management by management team and school parties. Also, the training is given by the absence of practice or simulation as the follow-up concerning financial reporting. This leads to many obstacles found out by BOS funds management team in Purwakarta Regency in terms of planning, implementation and reporting of BOS funds. Such condition ultimately drives the Education Office of Purwakarta Regency to develop a training model which can develop competence of BOS funds management team in the BOS management system.

Referring at results of study description above, it is necessary to conduct a development of model which can improve competence namely in the form of model development of Competence Based Training.The Competence Based Education and Training basically is one of the approach models in development of Human Resources which focuses on the outcomes. Such type of training model is designed to develop particular ability and skills in order to achieve work outcomes based on 
Performance Targetwhich has been determined in advance. CBT is a skill training approach emphasizing on what to be done by one person in work field after joining training (outcome) and representation of a shift from a pressure in inputting process in a training input. This more directs to training, particularly industry than to individual in a group (Brown, 1991).

\section{Literature Review}

Education is a process of improving common competence which is not merely related to one work career (Blanchard and Thacker, 2010). Meanwhile, training is a process of improving competence to conduct current and future tasks (Dessler, 2011). A training referred to improve employee competence should use competence-based training approach (Prabawati, et.al, 2017). Competence is a standard to be owned by an employee in completing his works and functions appropriately. Competence covers a number of attached attributes to individuals as a combination of knowledge, skills, and behaviour which can be used as a means to improve performance.

Competence is one's basic characteristic enabling excellence performance in specific work, role or situation. (Boulter, Dalziel dan Hill, 2003).

Competence can mean as character, attitude, and behaviour, or skills in completing works to be relatively stable if facing certain situation in workplace; it is formed by synergy between self-concept, intern motivation and contextual knowledge capacity. Competence includes some issues namely a) technical competence namely knowledge and skills to achieve agreed results, skills for problem solving and finding new alternatives, b) contextual competence is a kills to look at great illustration to test a number of control and perspective changes, c) competence for life is a skill for mutual dependence effectively with others, including skills to listen, communicate, obtain third alternative. Thus, competence serves as an importance factor of one having more skills leading to give difference from others having common skills (Covey, Roger, dan Merrill, 2003). A competence includes six aspects, namely Intellectual ability, Experience, skill, value, attitude, motivation, emotional issue (Zwell, 2008). Through competence-based training, it can improve all of the aspects which are internalized into their performance.

Excellence Competency-Based Education and Training emphasizes on necessary knowledge, skills and attitudes (competencies) in workplace in order to achieve skills to work with competent people. Some of the advantages of competency-based education and training as explained above include training with orientation to the work tasks that are carried out in an effective, efficient and practical manner in terms of education and training in managing the BOS fund management in Purwakarta. Through such a strict model, many education and training functions are as difficult as they are to be implemented, making them easier and more practical, because education and training process is structured and there are available educational materials and it has been based on an analysis on the development needs of competencies or analysis needs of the training, so as to enable active education and training.

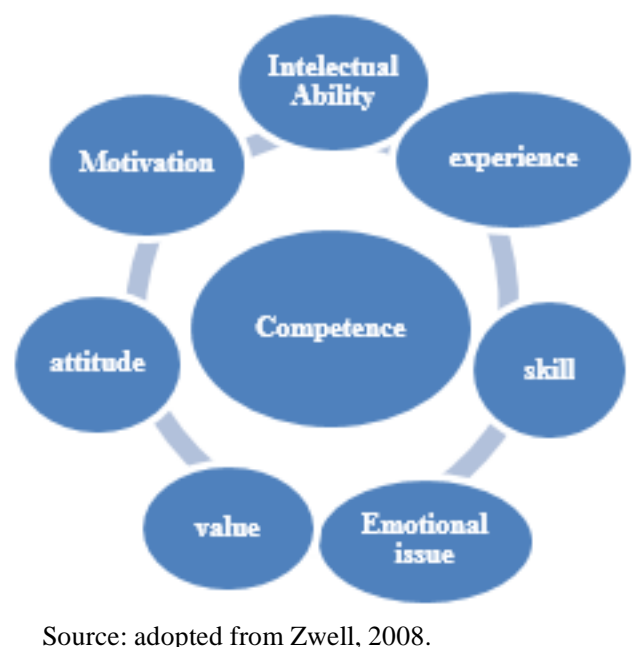

Figure 1. Six Competence Aspects

Competency-based training is one of the approaches in HR development with focus on the outcome. Competency-Based Education and Training is a process of education and training that is designed to develop specific abilities and skills, in order to achieve established performance-based performance targets. Therefore, Competency-Based Education and Training is very flexible in the process of opportunity to obtain competence by speaking (Hidayat \& Saud, 2015). CBT is a training model with advantages that can be relied upon by institutions to develop training programs. Preparation of the CBT program includes several stages, namely: (1) capability profiles, (2) select training programs, (3) produce personal training plans for each employee, (4) assessment competence (Irianto, J., 2001). At the end of this year, the organization was encouraged to continue monitoring the progress of each development as soon as the training was completed, continued with its implementation.

\section{Materials and Methods}

This research was conducted on Education Office of Purwakarta Regency as the subject in developing competency-based training model. The reason for choosing the Education Office of Purwakarta Regency is because this institution has a central role in developing the competence of the BOS fund management team at the school level. Considering this research focus is the development of a training model, the approach taken in this study uses research and development approach, using 
combined data analysis techniques namely qualitative and quantitative analysis. The procedure adopted in this study is in accordance with the approach as mentioned by (Borg and Gall, 2003) that in a research and development approach, researches design new products and procedures that must be systematically field-tested, evaluated, and improved to find certain effectiveness criteria. Furthermore, (Borg and Gall, 2003) revealed that new products and procedures in education are not merely in the form of material forms but also include whole products including processes or procedures such as methods, approaches, strategies and models for organizing learning.

The development of competence-based education and training used in this research is ADDIE (Analysis-Design-Develop-Implement-Evaluate) Learning Design Model combined by development research steps recommended by Borg and Gall by considering that the model is suitable for development of competence-based education and training for BOS fund management team in Primary Education level in Purwakarta Regency. The ADDIE (Analysis-Desain-Develop-Implement-Evaluate) instructional design model is a generic learning/training design model as the guidance in developing an effictive and dynamic training device and program infrastructure as well as supporting the training performance, so it can assist the training instructor in the training and learning management (Pargito, 2011). This ADDIE model uses 5 stages or steps of the development as seen in the following figure.

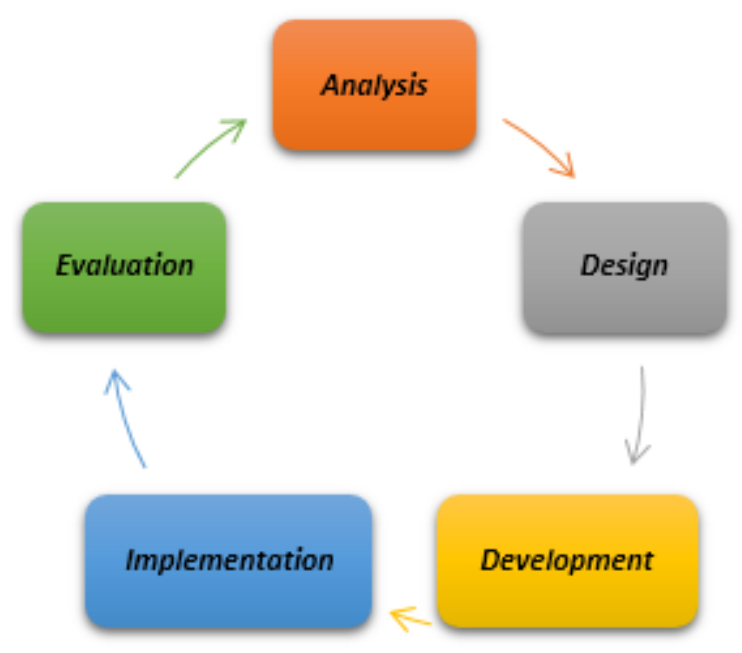

Figure 2. Steps of ADDIE Development Model

Based on the figure above, the steps of ADIIE development model, (Sugiyono, 2012) describes the above steps as follow:

\subsection{Analyze}

The analysis stage is a process of needs assessment, identifying problems (needs) and conducting a task analysis). The resulting output is in the form of characteristics or profiles of training participants, identification of needs and detailed task analysis based on needs.

\subsection{Design}

This stage is known as making a design (blue print), like a building so before it is built, there must be a design on paper first.

\subsection{Development}

This stage is the process of realizing the blueprint alias design into reality. This means that at this stage, any required things or that which will support the training process must all be prepared. There is also development of education and training design conducted through a testing process on a training model that has been previously designed. This is conducted to measure effectiveness and seek input that can enhance the development of models that have been done before.

\subsection{Implementation}

The implementation stage is a concrete step to implement the education and training system. That is, at this stage, everything that has been developed is installed or set in such a way according to its role or function so that it can be implemented. After the product is ready, it can be tested through large groups then evaluated and revised. Then, there will be trials on large groups and then re-evaluation and revise process so as to produce a final product that is ready for dissemination.

\subsection{Evaluation}

The evaluation stage is the process of seeing whether the learning system being built is successful, according to initial expectations or not. The evaluation phase can be conducted at each of the four stages above which are called formative evaluations, because the purpose is for revision needs. For example, at the design stage, it is necessary for expert reviews to provide input on the design we are making.

Referring at the description on the above steps, the development of competence-based education and training model using ADDIE development model is considered to be greatly appropriate. This is because, it will be easy to obtain an effective training model in the development of competence for BOS fund management team in Purwakarta Regencysince systematically this training model development is applied based on clear needs. This will facilitate the implementation of the training model design so it will be also easy to implement. By assistance of evaluation stage, this model development will be more 
meaningful since there will be feedback as a form of assessment on the implemented model development process.

\section{Results of Research}

The need analysis serves as a very important factor to achieve results of education and training. To conduct the need analysis for BOS team, it is conducted by:

1) comprehensive understanding of technical instructions

2) the ability to plan BOS funds management

3) the ability to implement BOS fund management planning

4) the ability to make financial reporting of BOS funds

5) the ability to use the BOS funds online reporting application.

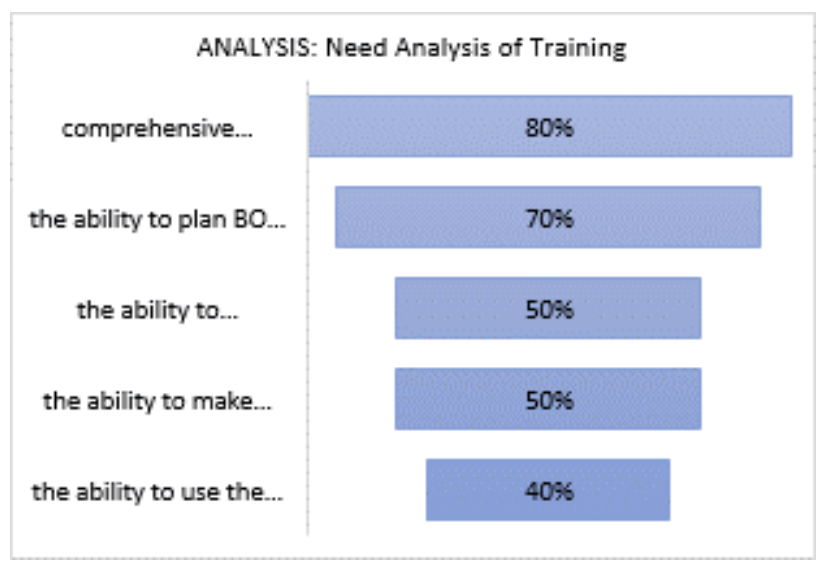

Based on the data above, it is known that there are yet adequate abilities to use applications, financial reports and implementation of BOS financial management. While, the ability to need analysis in terms of a comprehensive understanding of BOS regulations is well understood as well as for BOS planning.

In carrying out the needs analysis, the Education Office BOS Team has carried out the principles of the need analysis for this training namely individual differences, motivation, selection of trainers, active participation, focus on certain materials, diagnosis and correction, time sharing, seriousness, cooperation, training methods, and training relationships and the effective life of the training model.

\subsection{Design Stage}

The activity undertaken at this stage of developing the conceptual model is by carrying out preparation of the draft model, the activities conducted at this stage are:

a. Designing conceptual models of competency-based education and training on the results of theoretical studies, the objective conditions of the field, the results of relevant previous research studies, as well as formal provisions regarding the implementation of competency-based education and training.

b. Analyzing the gap between the competency profile of the BOS management team at the Primary Education level in Purwakarta Regency in carrying out their main tasks and functions as well as learning tasks in the education and training with ideal competencies according to formal provisions.

c. Describing the structure of the education and training model program to improve the competence of the BOS management team at the Primary Education level in Purwakarta Regency, and the framework of the education and training model.

d. Creating curriculum design and training materials in each training course that will be given to training participants.

\subsection{Development Stage}

The already prepared product design is developed based on the following steps:

a. The researchers combine the materials that had been collected according to the structure of the education and training model program to improve the competence of the BOS management team at the Primary Education level in Purwakarta Regency, and the framework of the education and training model. After that the researcher re-corrected the development media before it is validated, if it is appropriate then the product is ready to be validated.

b. Along with that there is a limited trial in the form of pre-training for 30 participants from each district. Based on the results of the trial until the trial results, it will conduct an evaluation process in order to measure the success and appropriateness of curriculum design and training courses.

c. Verifying or testing the feasibility of the conceptual model, namely by carrying out activities to improve and refine the initial design.

d. Conducting validation from experts on the development of designs that have been prepared namely from the Government Accounting Team and BPK Auditor Team in Purwakarta Regency.

\subsection{Conducting Model Implementation}

In the model implementation stage, the activities conducted to all BOS fund managers at the level of elementary and junior high schools in Purwakarta Regency are as follows:

a. The implementation of the education and training model is conducted as follows:

1) Carry out education and training, namely application of the competency-based education and training models that are developed. 
2) Evaluation activities in the implementation of the model include: evaluation of the education and training process (the model feasibility), evaluation of the results of education and training after implementation of education and training, and observations of the learning of the BOS management team at the Primary Education level in Purwakarta Regency in the reflection of results training.

b. Analysis of the implementation results of the education and training model developed, by taking the following activity steps:

1) Conducting data analysis before the implementation of education and training / implementation of the model (observations of BOS funds management before training) and after the implementation of education and training / implementation of models (observations of management of BOS funds after training), related to whether there is a change in mastery of competencies.

2) Analyzing data on the results of the BOS management team training at the Primary Education level in Purwakarta Regency as participants to find out whether there is a difference between the pretest results and the post-test results on competency mastery.

3) Analyzing data on differences in training results for the BOS management team at the Primary Education level in Purwakarta Regency, as intended to compare the differences as a basis for testing the improvement in the mastery competency of the BOS management team at the Primary Education level in Purwakarta Regency which is considered to be the effects of the implementation of the education and training model.

4) Analysis of the data undertaken as mentioned above, is intended to find out whether the developed education and training model is effective for improving the competence of the BOS management team at the Primary Education level in Purwakarta Regency.

\subsection{Evaluation Stage}

Evaluation on the results of the model implementation is conducted through post-education and training testing activity in order to obtain data on mastery of the competence of the BOS management team at the Primary Education level in Purwakarta Regency as stated in the post-implementation needs assessment model.

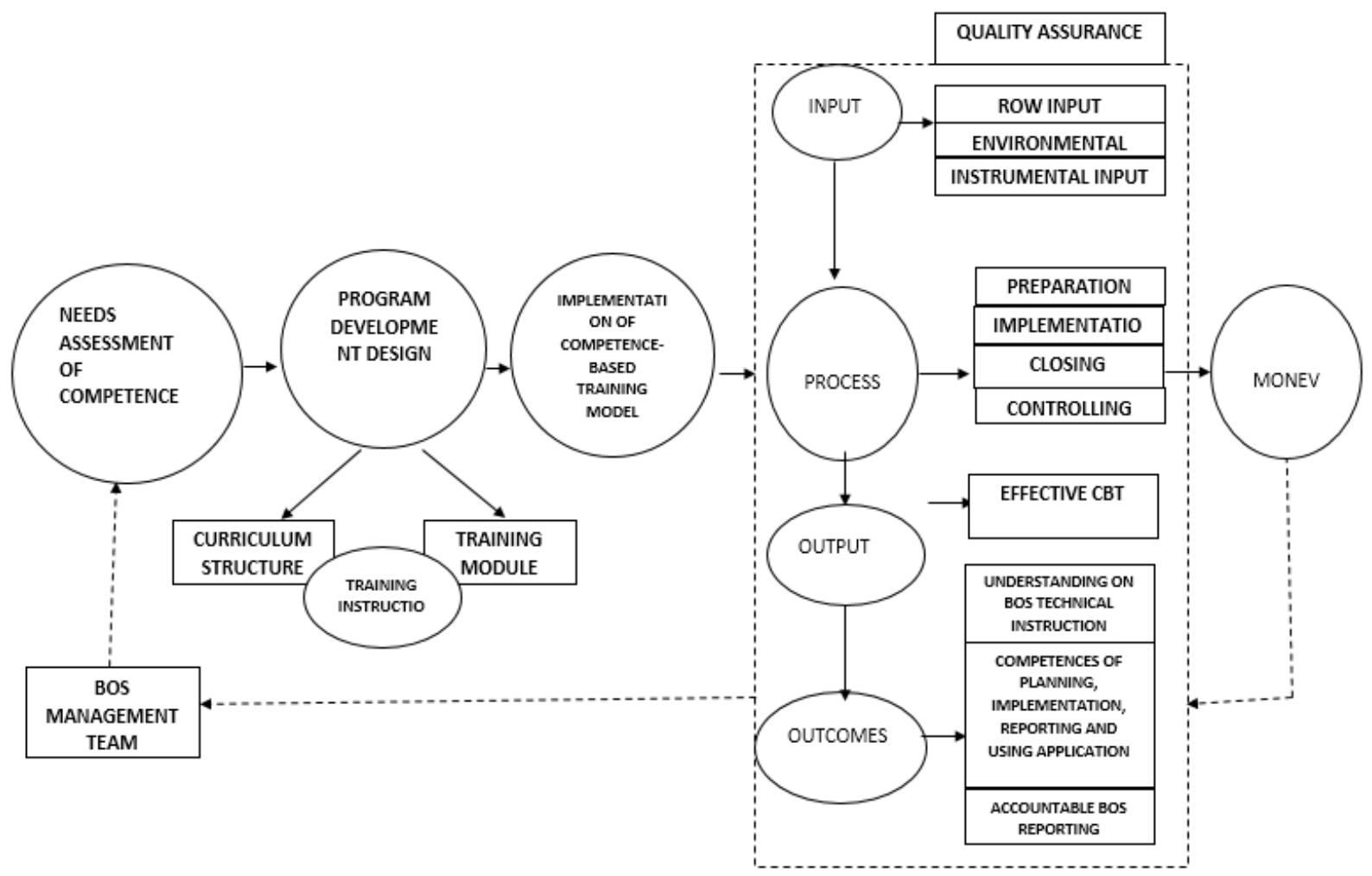

Figure 2. Implementation of Competence-based Training Model for BOS Management Team in Primary Education level in Purwakarta Regency 


\section{Discussion}

Referring at the above research steps, it can be stated that in general, the prepared procedure in development of competence-based training model has been prepared systematically and in a sustainable manner with other components, so the competence-based training model is greatly suitable for use in improving competence of BOS funds management team in Purwakarta Regency. This is in line with a research conducted by (Hidayat and Sa'ud, 2015) expressing that a competence-based training model for Civil Servant category III/c and III/d (Widyaiswara Muda) in the environment of Ministry of Domestic Affairs of the Republic of Indonesia. In this study, it was stated that the capacity and competency of the HR Apparatus must continue to be improved and utilized in the framework of carrying out government tasks in accordance with the spirit of bureaucratic reform in order to realize good governance. To achieve this, it can be conducted in various ways, one of which is through apparatus education and training. Therefore, it is necessary to continuously improve, refine, update and adjust the apparatus education and training the apparatus education and training to the development of the environment at the local, national and global levels which is conducted thoroughly in terms of institutions, systems, human resources and the substance of the training.

Meanwhile in another study (Helnikusdita, 2016) it shows that management of BOS funds is taken through four stages namely planning, implementation, reporting and evaluation. In the planning stage, the use of School Operational Assistance (BOS) funds is started with preparation of the School Expenditure Budget and Expenditure Plan (RAPBS), which is a plan for obtaining education funding from various sources of income as well as an annual work program composition consisting of a number of routine activities as well as several other activities accompanied by details its financing plan for one fiscal year.

The needs assessment is very important to achieve the expected training objectives. In a study conducted by (Widodo, et al, 2015), it was said that effective training is a training that is able to achieve the established goals. Furthermore (Widodo, et al, 2015) effective education and training must consider any principles leading to its success in a education and training, especially to improve professional competence of Physics teachers in creation of KTI. The principles are in the forms of individual differences, motivation, choice of trainers, active participation, focus on specific materials, diagnosis and correction, time sharing, seriousness, cooperation, training methods, and the relationship of training with real life which will be considered in developing an effective training model (Widodo, et al., 2015). This statement is also supported by results of a research by (Rachman, 2017) on training and development of character education. Basically, to achieve this goals, it must be conducted continuously and systematically, in order to obtain maximum results. Based on this, it can be said that the needs assessment is a very important and determinant initial step to achieve an effective and efficient training.

\section{Conclusions}

School operational assistance is assistance in the form of costs given by central government to schools, ranging from primary education to secondary education. The program aims to reduce Education cost burden given to the society in order to accomplish a qualified 12-year-complusory education. The existence of BOS is greatly useful and requires accountable reporting supported by reliable, competence and responsible team. BOS team education and training requires competence education and training approach so that the team can have skills in BOS management effectively and efficiently. The stages in developing competence-based BOS education and training are started by: 1) Analysis stage; 2) Design stage; 3) Developing stage 4) Implementation stage; and 5) Evaluation stage by paying attention to learning principles namely: individual differences, motivation, selection of trainers, active participation, focus on certain materials, diagnosis and correction, time sharing, seriousness, cooperation, training methods, and training relationships with real life.

\section{REFERENCES}

[1] Blanchard and Thacker. (2010). Effective Training: System, Strategies, Practice. New York: Publisher Pearson Education

[2] Branch, R. M. (2009). Instructional Design-The ADDIE Approach. New York: Springer.

[3] Brown, M. W. (1991). Competency Based Education and Behavioural Objective, Englewood Cliffs, Education Technological. Publication Inc. New Jersey.

[4] Boulter, Nick, Dalziel, Murray dan Hill, Jackie. 2003. People and Competence. Jakarta: PTGramedia.

[5] Castetter, W. B. (1999). The Personnel Function in Educational Administration Third Edition. New York: Macmillan \& Co.

[6] Covey R. Stephen, A. Roger Merrill, Rebecca R. Merrill, (2003). First Things First. NewYork: Free Press.

[7] Dessler, Gary, (2011). Humana Resource Management. Twelfth Edition. New Jersey: Pearson Prentice Hall.

[8] Dugan. (1984). Competency Base Training: P. systematic Approach Information State.

[9] Gall, M.D \& Borg, W. (2003). Educational Research An Introduction Seventh Edition. London: Pearson Education 
Inc.

[10] Helnikusdita. (2016). Implementation of School Operational Assistance Funds (BOS). Journal: Educational Manager, Volume 10, Number 6, page. 527-539.

[11] Hidayat, A. And Sa'ud, U. (2015). Competence-based Education and Training Model for Young Widyaiswara. Education Administration Journal Vol.XXII No.2

[12] Irianto, J. (2001). Human Resource Management. Surabaya: Insan Cendekia

[13] Prabawati, et.all, 2017. Effects of Debt to Equity Ratio, Market to Book Value, and Liquidity Factors on Decision of Hedging Using Derivative Instruments. Business Administration Journal (JAB), Vol. 69 No. 1.

[14] Pargito. 2009. Research and Development of Education Sector. Department of Education IPS Lampung University. Bandar Lampung.

[15] Rachman, M. (2017). Development of Training Management Model and Development of Character Education with Character Focus. Education Reflection Journal 8 (1)

[16] Sugiyono. (2012). Understanding Qualitative Research. Bandung: Alfabeta.

[17] Sugiyono. (2015). Quantitative Qualitative Research Method and R\&D. Bandung: Alfabeta.

[18] Widodo, K.S. (2015). Development of Education and Training Model of Participative Integrative Collaborative (PIKOLA) to Improve Senior High Physic Teacher Professionalism Competence. Educational Management Journal ISSN 2252-7001 Hal. 116-124

[19] Zwell, Micahel. 2008. Creating a Culture of Competence. New York: John Wiley and Sons, Inc. 